\title{
Kajian Teknis Prinsip dan Mekanisme Kerja Crystallizer pada Pemurnian Timah
}

\author{
Muhammad Ikrar Lagowa ${ }^{1, *}$, Machmud Hasjim ${ }^{2}$, Taufik Arief ${ }^{2}$, Yosa Megasukma ${ }^{1}$ \\ ${ }^{1}$ Universitas Jambi, Fakultas Sains dan Teknologi, S1 Teknik Pertambangan, Jambi, Indonesia \\ ${ }^{2}$ Universitas Sriwijaya, Fakultas Teknik, S1 Teknik Pertambangan, Indralaya, Indonesia \\ * Corresponding author: mikrarlagowa@unja.ac.id \\ Received: May 20, 2021; Accepted: June 16, 2021. \\ DOI: $10.31764 /$ jpl.v2i1.4711
}

\begin{abstract}
Abstrak. Teknologi pemurnian logam campuran (alloy) $\mathrm{Sn}-\mathrm{Pb}$ menggunakan crystallizer telah digunakan pada proses pemurnian timah di Indonesia sejak lama, namun referensi dan kajian terkait alat ini masih sangat terbatas. Penelitian ini bertujuan untuk mengkaji prinsip dan mekanisme kerja dari crystallizer agar didapatkan pemahaman yang lebih baik terhadap penggunaan teknologi ini ke depannya. Penelitian ini dilakukan dengan mengambil data-data operasional crystallizer berupa data suhu dan komposisi awal umpan, temperatur palong crystallizer, temperatur material pada setiap zona, kadar $\mathrm{Pb}$ pada setiap zona, kadar $\mathrm{Pb}$ kristal, jumlah sampan, kecepatan putaran bilah, serta pengamatan terhadap karakteristik penyemprotan dan operator. Data-data ini kemudian disajikan dalam bentuk tabel dan grafik lalu diinterpretasikan berdasarkan teori dan penelitian sebelumnya. Dari hasil penelitian didapatkan bahwa temperatur palong pada zona 3-5 dijaga di atas titik lebur $\mathrm{Pb}$ agar kristal $\mathrm{Pb}$ mencair dan turun ke zona 1, sedangkan temperature material di bagian atas dijaga di bawah titik lebur Sn agar kristal Sn tetap dalam fase padatan. Peningkatan kecepatan putaran bilah meningkatkan produksi kristal Sn. Selain itu, penyemprotan oleh operator sangat penting untuk mencapai kristalisasi campuran logam $\mathrm{Pb}-\mathrm{Sn}$. Dari penelitian ini dapat disimpulkan bahwa pemurnian campuran PbSn menggunakan crystallizer dipengaruhi temperatur operasi, kecepatan putaran bilah, dan penyemprotan oleh operator.
\end{abstract}

Kata Kunci: crystallizer, diagram eutectic $\mathrm{Pb}-\mathrm{Sn}$, pemurnian timah

\begin{abstract}
Refining technology of $\mathrm{Sn}-\mathrm{Pb}$ alloy using crystallizer has been used for tin refining in Indonesia, yet there is limited number of studies and references discussing this topic. This research was aimed to study working principle and mechanism of crystallizer to obtain deeper understanding of its usage. This research was done by collecting operational data related to crystallizer such as feed composition and temperature, temperature of crystallizer chamber, temperature and $\mathrm{Pb}$ content of material in each zone, $\mathrm{Pb}$ content of crystallized Sn, the number of crystal box, blades' rotation speed, and observation of spraying and operator. These data were presented in graphics and tables and then interpreted based on related theories and previous studies. The results showed the chamber temperatures in zone 3 to 5 were kept above the melting point of $\mathrm{Pb}$ to transform $\mathrm{Pb}$ phase from solid to liquid and flow to zone 1, while the temperature of crystallized $\mathrm{Sn}$ was kept below its melting point to keep it in solid phase. Increasing blade rotation rate resulted in higher production of crystallized Sn. Also, water spraying has significant impact on crystallization of $\mathrm{Sn}-\mathrm{Pb}$ alloy. It can be concluded that refining of $\mathrm{Sn}-\mathrm{Pb}$ alloy was highly affected by operating temperature, blade rotation rate, and water spraying.
\end{abstract}

Keywords: crystallizer, eutectic diagram $\mathrm{Pb}$-Sn, tin refining

\section{Pendahuluan}

Diantara produk utama berbahan baku timah adalah timah solder dalam bentuk batang solder (solder bar). Terdapat dua jenis batang solder, yaitu yang masih mengandung timbal $(\mathrm{Pb})$ solder dan yang tidak mengandung $\mathrm{Pb}$ (lead free) (Salim dan Munadi, 2016). Maka dalam penamaan merek dagang produk timah yang terdaftar di London Metal Exchange (LME), kadar $\mathrm{Pb}$ menjadi komponen tak terpisahkan, sebagai contoh Banka Tin Low Lead (LL200, LL100, dan LL50) dimana angka 200, 100, dan 50 menunjukkan kadar $\mathrm{Pb}$ maksimum di dalam produk batangan timah (tin bar) (European Chemicals Agency (ECHA), 2020). 
Pemurnian logam campuran (alloy) $\mathrm{PbSn}$ dari $\mathrm{Pb}$ dicapai melalui metode fractional crystallization / solidification menggunakan Yunnan crystallizer (Drini, Katgerman dan Boom, 2005). Teknologi ini dikembangkan di Cina tahun 1975 dan masih dipergunakan oleh perusahaanperusahaan timah termasuk Indonesia. Pemisahan $\mathrm{Sn}$ dan $\mathrm{Pb}$ pada crystallizer memanfaatkan perbedaan SG dan titik lebur kedua unsur logam tersebut (SG Sn 7,2-7,5 dan titik lebur $232^{\circ} \mathrm{C}, \mathrm{SG}$ $\mathrm{Pb} 11,34$ dan titik lebur $327^{\circ} \mathrm{C}$ ). Pembentukan kristal PbSn dicapai pada temperatur eutectic $183{ }^{\circ} \mathrm{C}$ melalui penyemprotan oleh operator, sedangkan pembentukan logam cair $\mathrm{Pb}$ dicapai menggunakan elemen pemanas elektrik pada crystallizer. Transportasi kristal Sn yang telah dimurnikan sebagai produk akhir menggunakan bilah-bilah yang berputar. Skema alat crystallizer selengkapnya dapat dilihat pada Gambar 1. Alat ini terdiri dari sebuah palong/bak berbentuk setengah tabung yang diposisikan pada kemiringan tertentu yang didalamnya terdapat bilah-bilah yang berputar serta elemen pemanas pada bagian bawah palong. Terdapat 5 zona pada alat ini yang dimulai dari zona 1 pada bagian paling bawah dan zona 5 pada bagian paling atas.

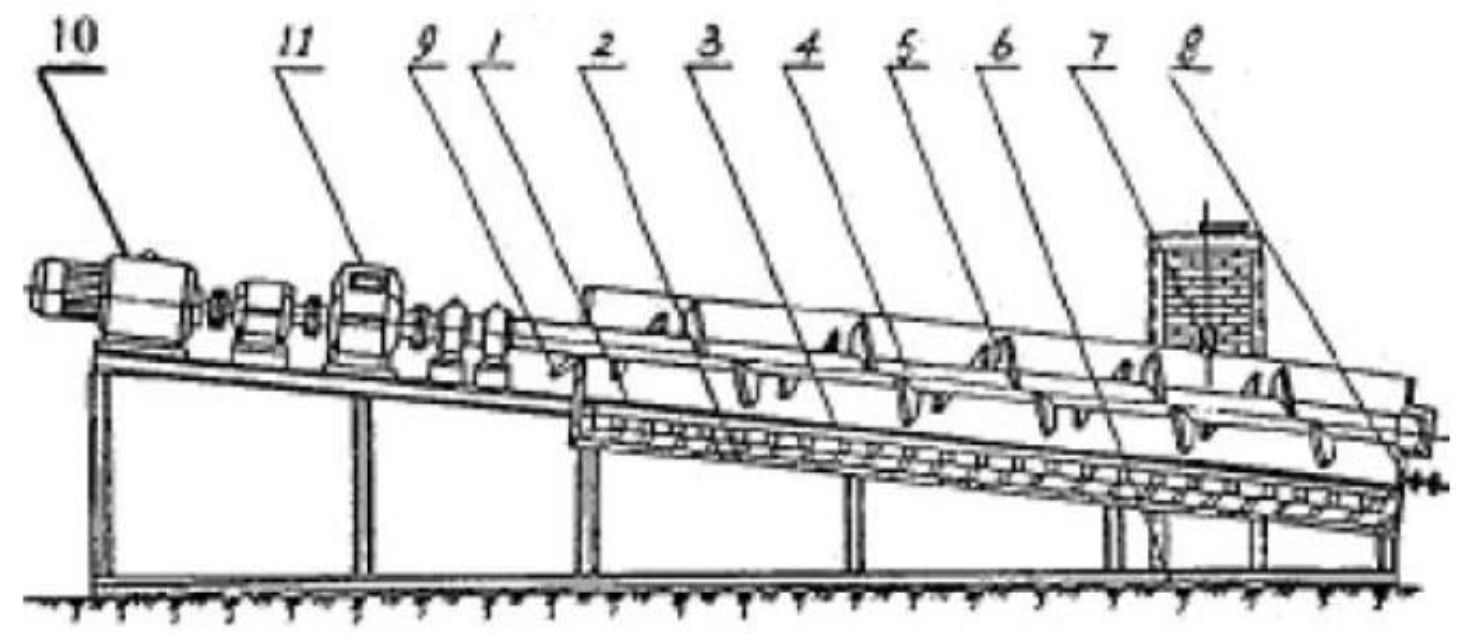

Gambar 1. Skema Alat Yunnan Crystallizer (Drini, Katgerman dan Boom, 2005; Drini, 2006)

Kajian terkait teknologi pemurnian logam campuran $\mathrm{PbSn}$ menggunakan crystallizer masih sangat terbatas: teori dasar terkait diagram fasa Pb-Sn dijelaskan oleh (Heyer, 1939). Penjelasan tentang sejarah serta prinsip kerja alat ini dijelaskan secara menyeluruh oleh Drini dkk., (2005) dan Drini (2006), prosedur operasi standar penggunaan crystallizer timah diuraikan dengan jelas oleh Barata (2006), dan penelitian terkait dilakukan oleh (Arief dan Gumilang, 2011).

Penelitian ini bertujuan untuk mengkaji secara teknis prinsip dan mekanisme kerja crystallizer pada proses pemurnian logam campuran $\mathrm{PbSn}$ berdasarkan teori yang tersedia. Dari penelitian ini diharapkan akan didapatkan pemahaman yang lebih menyeluruh dan mendalam terhadap prinsip dan mekanisme crystallizer untuk memenuhi keterbatasan informasi terkait alat ini.

\section{Metode Penelitian}

Penelitian ini dilakukan di unit metalurgi sebuah perusahaan timah di Provinsi Bangka Belitung. Penelitian ini dilakukan dengan mengumpulkan data-data primer dan sekunder terkait operasional crystallizer. Data primer yang diambil meliputi: temperatur material di setiap zona di dalam palong, kadar $\mathrm{Pb}$ umpan, kadar $\mathrm{Pb}$ material di setiap zona, kadar $\mathrm{Pb}$ kristal $\mathrm{Sn}$, dan pengamatan terhadap kinerja operator penyemprotan. Sedangkan data sekunder yang didapatkan meliputi temperatur umpan, temperatur setiap zona di dalam palong dan kecepatan putaran bilah-bilah crystallizer.

Temperatur material di setiap zona diukur secara langsung menggunakan thermocouple. Kadar $\mathrm{Pb}$ umpan didapatkan dari data sekunder hasil analisa timah harian pada ketel pemurnian. Untuk mengetahui kadar $\mathrm{Pb}$ material di setiap zona dan kristal $\mathrm{Sn}$, dilakukan pengambilan sampel secara langsung dari setiap zona dalam bentuk lempengan, lalu sampel tersebut dibawa ke laboratorium untuk dianalisis menggunakan Inductive Couple Plasma (ICP). Temperatur umpan, temperatur setiap zona di dalam palong, dan kecepatan putaran bilah-bilah crystallizer didapatkan dari panel kontrol. Karakteristik penyemprotan dan operator didapatkan dari hasil pengamatan secara langsung. Data- 
data yang telah didapatkan kemudian disajikan dalam bentuk grafik dan tabel lalu diinterpretasikan dan dikaji dengan membandingkannya dengan referensi dari kajian pustaka dan penelitian-penelitian terkait.

\section{Hasil dan Pembahasan}

\subsection{Diagram Fase Pb-Sn}

Crystallizer bekerja berdasarkan prinsip eutectic refining menggunakan diagram fase $\mathrm{Pb}-\mathrm{Sn}$ (Heyer, 1939). Untuk memasukkan kondisi operasi crystallizer hasil penelitian ke dalam diagram fase $\mathrm{Pb}-\mathrm{Sn}$ (Gambar 2) maka diperlukan data-data berupa komposisi umpan (\% Sn dan \% Pb), temperatur umpan, dan temperatur material kristal yang terbentuk karena pendinginan oleh penyemprotan. Penyemprotan dilakukan di zona 2, namun pengukuran suhu kristal tepat saat ia terbentuk tidak bisa dilakukan. Maka titik pengukuran terdekat adalah kristal di zona 2.

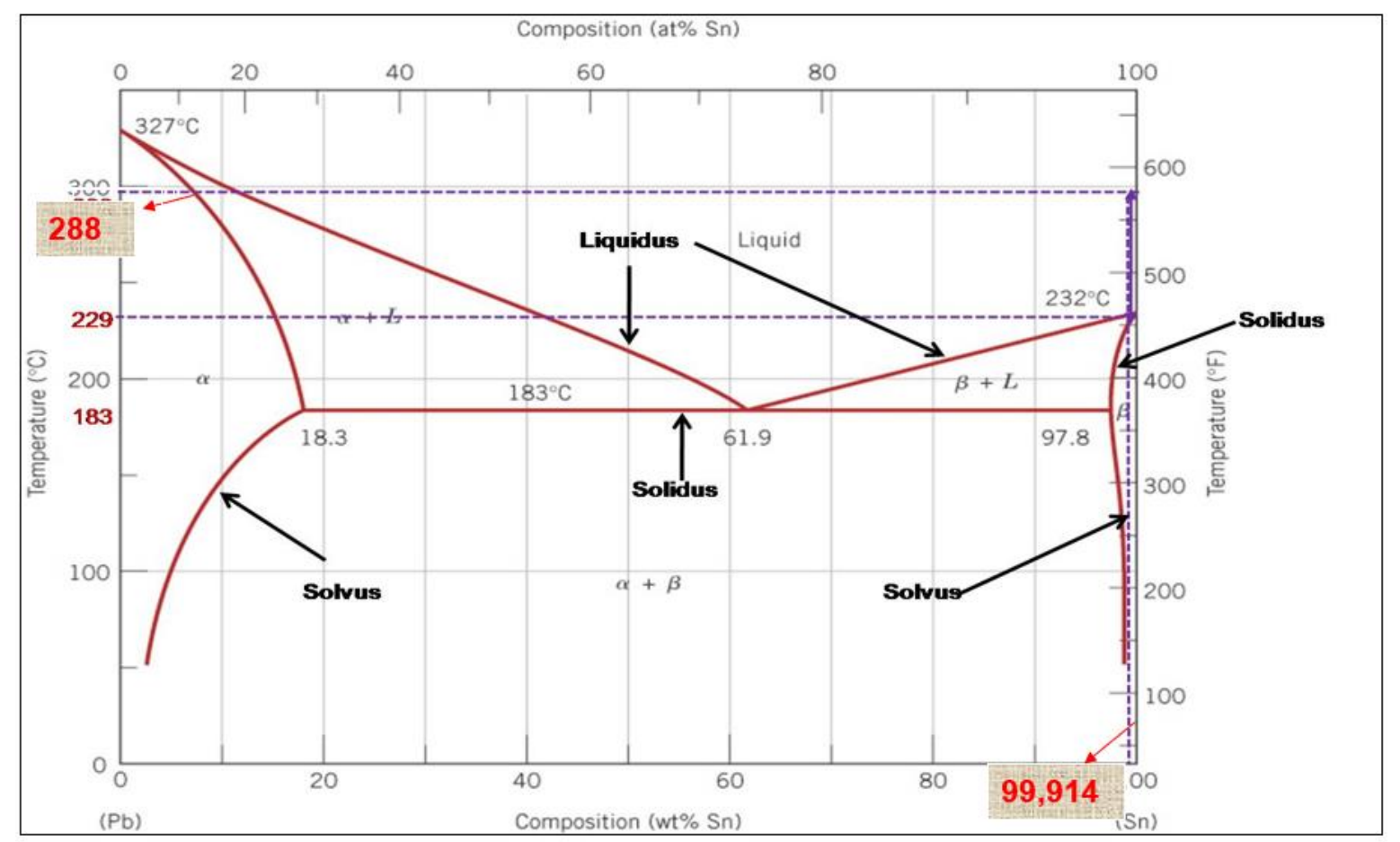

Gambar 2. Diagram Fase Pb-Sn Hasil Penelitian

Komposisi umpan didapatkan dari rata-rata kadar Sn dalam umpan yaitu 99,914 \% Sn. Temperatur umpan didapatkan dari temperatur rata - rata holding pot yaitu $288{ }^{\circ} \mathrm{C}$. Sedangkan temperatur kristal yaitu $229{ }^{\circ} \mathrm{C}$. Pada komposisi ini, pengkristalan yang terjadi pada suhu $229{ }^{\circ} \mathrm{C}$ akibat penyemprotan menghasilkan kristal $\beta$ (kaya Sn) dengan komposisi sama dengan umpan. Ketika kadar Sn semakin turun (bergerak ke kiri) maka waktu yang dibutuhkan untuk membentuk kristal akan semakin lama. Oleh karena itu, dengan kadar $\mathrm{Pb}$ yang tinggi, maka semakin lama waktu yang diperlukan campuran untuk membentuk kristal (Heyer, 1939)

Pada suhu sekitar $231^{\circ} \mathrm{C}$, cairan timah mulai mengkristal dan memasuki fase liquid $+\beta$, dan pada saat menyentuh garis solidus (padatan), terbentuk kristal $\beta$ yang kaya Sn dengan komposisi sesuai komposisi awalnya. Kondisi ini terus berlangsung selama penurunan temperatur. Maka penyemprotan hanya berfungsi membentuk kristal, namun tidak menurunkan kadar $\mathrm{Pb}$ dalam timah.

\subsection{Suhu Material dan Suhu Palong pada Setiap Zona}

Untuk melihat hubungan suhu material dan suhu palong pada setiap zona, dibuat diagram suhu material dan suhu palong rata-rata pada setiap zona crystallizer dan titik lebur $\mathrm{Pb}$ serta $\mathrm{Sn}$ (Gambar 3). Pemanasan pada palong berguna untuk mencairkan $\mathrm{Pb}$ agar timah termurnikan. Maka dari Gambar 3 dapat dilihat bahwa suhu palong pada zona 3 sampai 5 dijaga agar selalu di atas titik lebur $\mathrm{Pb}$ agar kristal $\mathrm{Pb}$ yang berada di bagian bawah mencair dan turun ke zona 1, sedangkan suhu 
kristal Sn di bagian atas (suhu material) dijaga agar selalu di bawah titik lebur Sn agar kristal Sn tidak mencair dan ikut turun bersama $\mathrm{Pb}$ (Gambar 4). Pada proses inilah terjadi penurunan kadar $\mathrm{Pb}$. Hasil ini berbeda dengan dengan hasil penelitian Arief \& Gumilang (2011) dimana pengaturan temperatur palong menurun dari zona 5 ke zona 1 (kecuali pada zona 3 dan 4) yaitu 550, 475, 350, 350 , dan $300{ }^{\circ} \mathrm{C}$ secara berturut-turut. Pada hasil pengamatan temperatur aktual yang dilakukan penulis, temperatur palong pada zona 4 lebih rendah dibandingkan pada zona 3 dikarenakan ada kerusakan pada elemen pemanas.

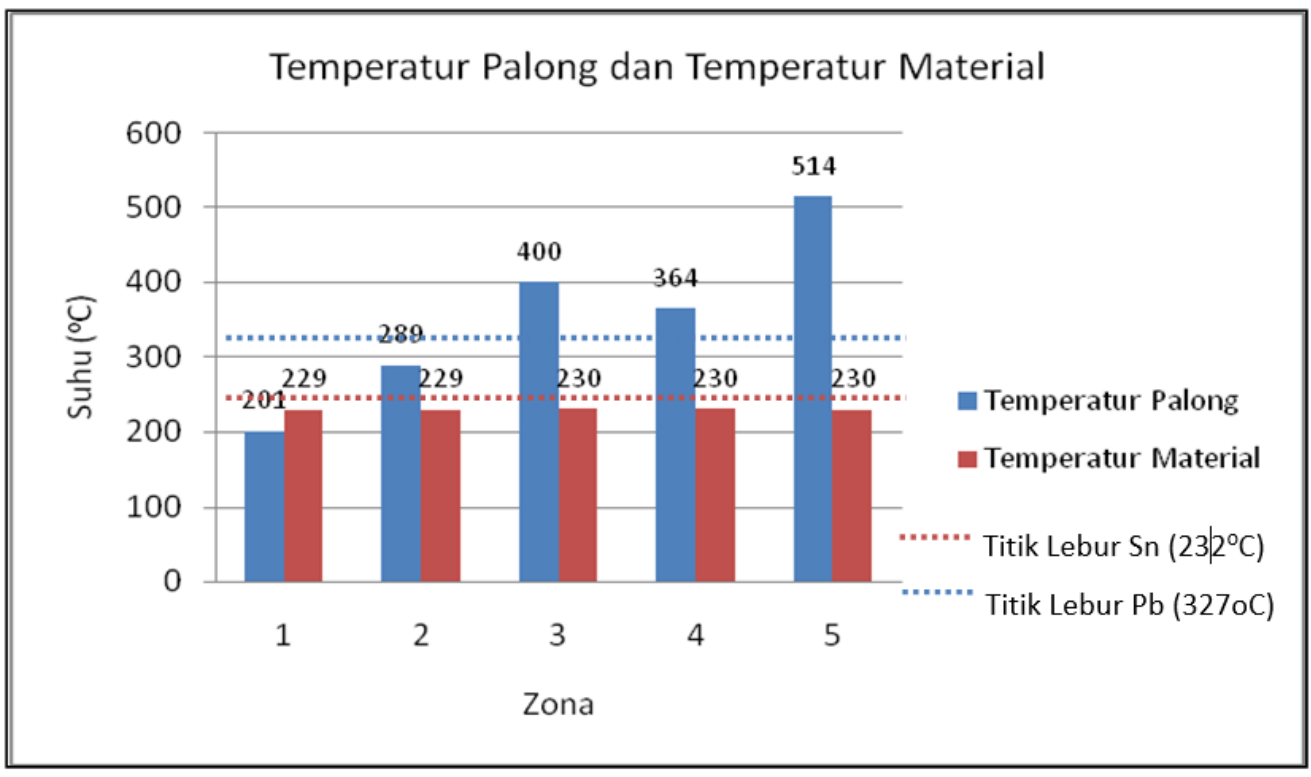

Gambar 3. Perbandingan Temperature Palong dan Material pada setiap Zona Crystallizer

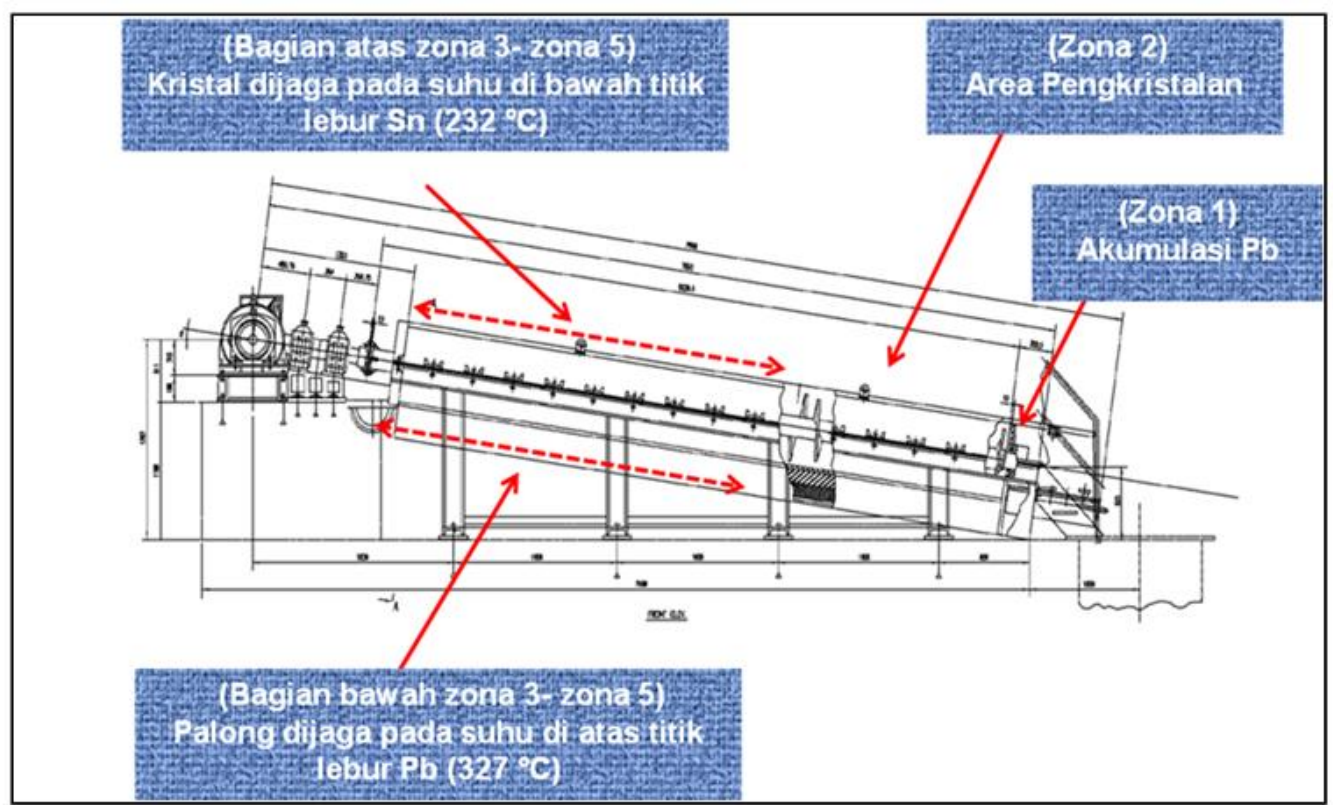

Gambar 4. Ilustrasi Zonasi Temperatur pada Crystallizer

\subsection{Penurunan Kadar $\mathrm{Pb}$ pada Zona-zona Crystallizer}

Perbedaan suhu setiap zona pada crystallizer dimaksudkan untuk menurunkan kadar $\mathrm{Pb}$ dalam timah (Barata, 2006). Semakin tinggi suhu dari zona 1 sampai zona 5, maka akan semakin berkurang kadar $\mathrm{Pb}$ pada masing-masing zona tersebut. Berdasarkan hal ini maka diambil sampel timah dari masing-masing zona untuk analisa kadar $\mathrm{Pb}$ selama 8 kali (1 kali pengambilan data per hari). 
Dari Gambar 5, dapat dilihat bahwa ada suatu trend penurunan kadar $\mathrm{Pb}$ dari zona 1 sampai zona 5. Ini membuktikan bahwa crystallizer efektif untuk menurunkan kadar $\mathrm{Pb}$ dalam timah. Dari data juga bisa dilihat bahwa penurunan yang signifikan terjadi dari zona 2 ke zona 3 . Ini disebabkan karena walaupun akibat penyemprotan, kristal mulai terbentuk di zona 2, namun cairan di zona 1 yang kaya $\mathrm{Pb}$ menggenang sampai ke zona 2 , sedangkan di zona 3 keseluruhan material sudah dalam bentuk kristal, didukung pula oleh suhu palong pada zona 3 yang lebih tinggi dari titik lebur $\mathrm{Pb}$, menyebabkan $\mathrm{Pb}$ mencair dan terpisahkan. Zona 1 merupakan zona penumpukan $\mathrm{Pb}$ maka kadar $\mathrm{Pb}$ di zona 1 terus bertambah.

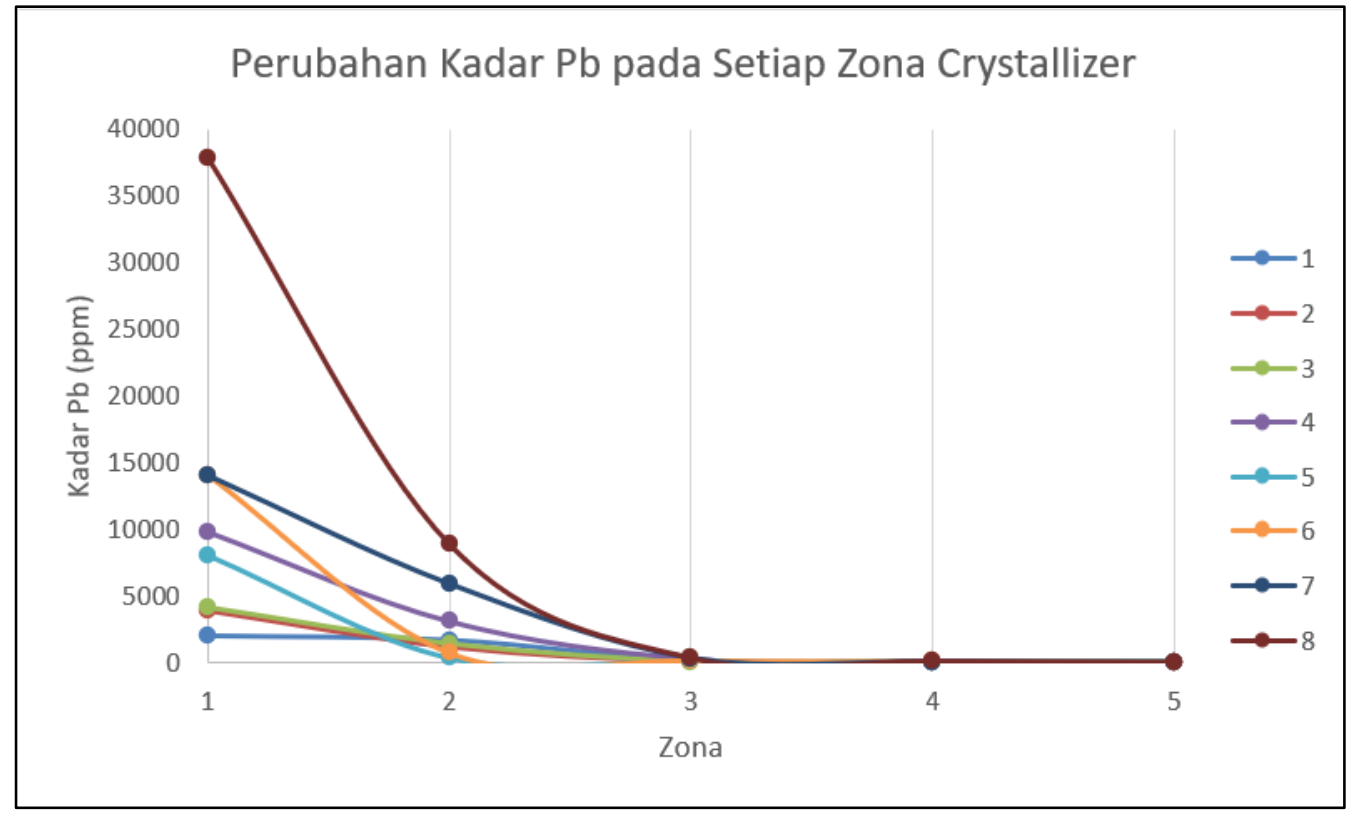

Gambar 5. Perubahan Kadar Pb pada Zona Crystallizer

\subsection{Perbandingan Kadar Pb Umpan dan Produk Kristal}

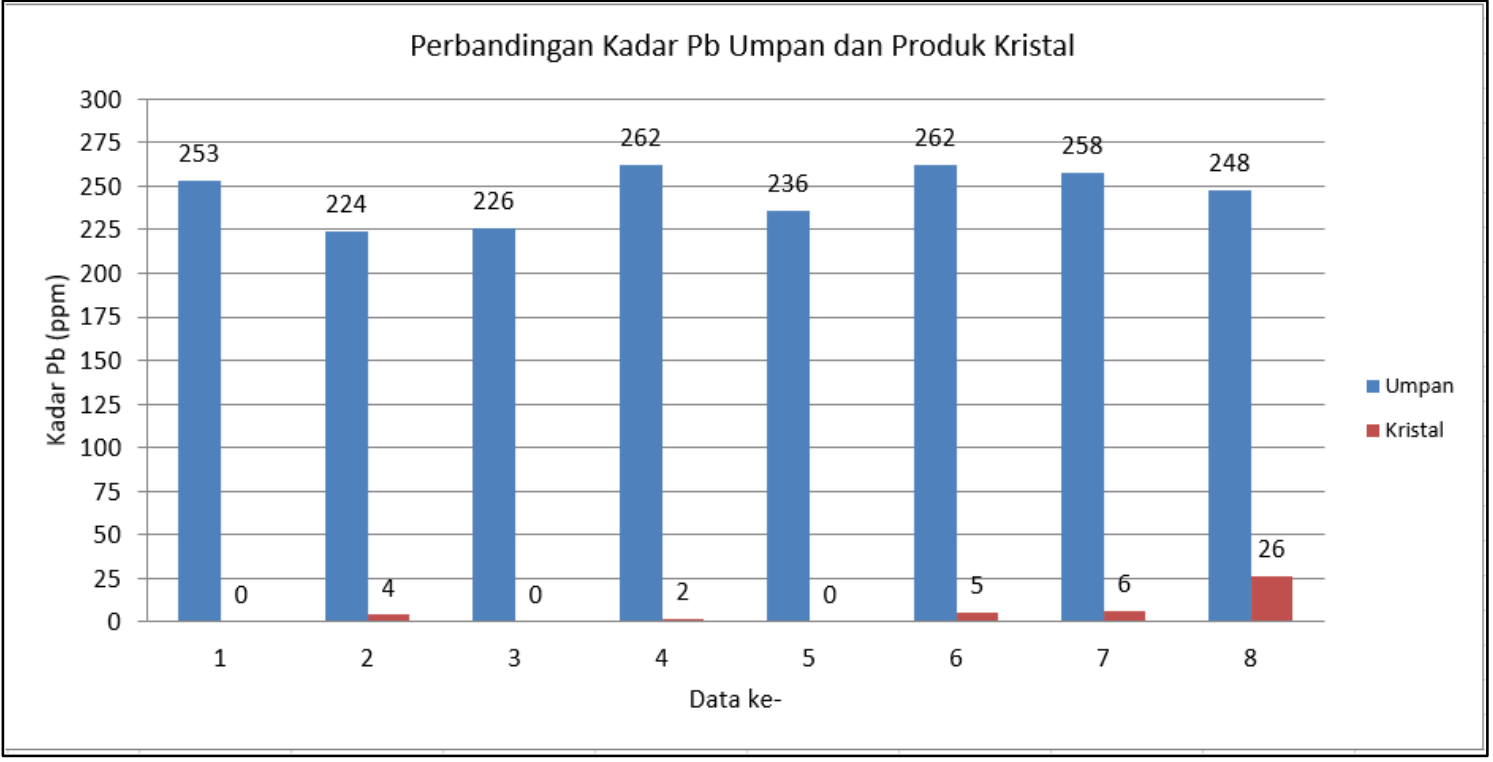

Gambar 6. Perbandingan Kadar Pb Umpan dan Produk Kristal

\subsection{Hubungan Kecepatan Putaran Bilah Cystallizer dan Jumlah Sampan}

Menurut Arief dan Gumilang (2011), semakin cepat putaran bilah maka semakin banyak produksi kristal Sn yang dihasilkan di dalam sampan (crystal box), karena semakin cepat pendorongan kristal dari zona ke zona sampai ke sampan, akan tetapi juga akan terjadi peningkatan kadar $\mathrm{Pb}$ pada produk kristal Sn karena sebagian kristal Pb tidak sempat melebur dan terikut dengan kristal Sn. Sebaliknya, 
semakin lambat putaran bilah, maka produksi akan berkurang, namun kemurnian kristal $\mathrm{Pb}$ juga meningkat.

Tabel 1. Pengaruh Kecepatan Putaran Bilah terhadap Produksi Kristal Sn

\begin{tabular}{lcccc}
\hline RPM bilah & 700 & 750 & 800 & 850 \\
\hline Jumlah sampan & 4 & 4 & 5 & 5
\end{tabular}

Dari Tabel 1 dapat dilihat bahwa ketika kecepatan mencapai $800 \mathrm{rpm}$ ke atas, total produksi bisa mencapai 5 sampan atau $\pm 7,5$ ton. Namun jumlah sampan juga dipengaruhi penyemprotan oleh operator. Jika operator jarang melakukan penyemprotan, maka kristal yang terbentuk juga makin sedikit, dan waktu yang dibutuhkan untuk mengisi satu sampan juga makin lama.

\subsection{Penyemprotan dan Operator}

Penyemprotan dilakukan untuk membentuk kristal di zona 2 dan menjaga temperatur kristal di zona 3 dan 4. Namun, dari hasil pengamatan, terkadang operator melakukan penyemprotan di zona 1 sehingga kadar $\mathrm{Pb}$ di zona 2 bisa naik drastis. Menurut Arief dan Gumilang (2011), durasi penyemprotan juga berpengaruh terhadap komposisi produk crystallizer. Apabila penyemprotan dilakukan relatif lama, maka akan terbentuk kristal $\mathrm{Pb}$ yang akan terbawa bersama kristal $\mathrm{Sn}$, sedangkan apabila penyemprotan dilakukan sebentar, maka kristal Sn akan mencair dan turun bersama $\mathrm{Pb}$ cair.

Operator juga harus teliti memperhatikan material di palong, bila kristal yang terbentuk sedikit, maka harus memperbanyak penyemprotan di zona 2, dan bila ada penumpukan kristal, harus cepat dilakukan barring. Namun teknik barring yang dilakukan terutama pada bilah umumnya dapat merusak karena bilah yang berada dalam keadaan panas dipukul dengan besi yang berat sehingga kemiringan bilah berubah.

\section{Kesimpulan}

Dari penelitian ini dapat dirumuskan beberapa kesimpulan sebagai berikut:

1. Crystallizer sangat efektif menurunkan kadar $\mathrm{Pb}$ dari alloy $\mathrm{Pb}-\mathrm{Sn}$ dengan efektifitas rata-rata mencapai $97,84 \%$.

2. Efektifitas pemisahan $\mathrm{Sn}$ dan $\mathrm{Pb}$ sangat dipengaruhi faktor: pengaturan temperatur operasi, kecepatan putaran bilah, dan penyemprotan.

3. Penurunan kadar $\mathrm{Pb}$ yang sangat besar terjadi dari zona 2 ke zona 3. Sedangkan kadar $\mathrm{Pb}$ pada zona 1 selalu meningkat.

4. Suhu palong crystallizer pada zona 3 sampai 5 dijaga agar selalu di atas titik lebur $\mathrm{Pb}\left(327{ }^{\circ} \mathrm{C}\right)$ agar kristal $\mathrm{Pb}$ yang berada di bagian bawah mencair dan turun ke zona 1 . Sedangkan suhu kristal Sn di bagian atas dijaga agar selalu di bawah titik lebur Sn $\left(232^{\circ} \mathrm{C}\right)$ agar kristal Sn tidak mencair dan ikut turun bersama $\mathrm{Pb}$.

5. Semakin cepat putaran bilah, maka jumlah produk pemurnian dalam bentuk kristal Sn semakin meningkat, namun dapat berpengaruh pada kadar $\mathrm{Pb}$ di dalamnya.

6. Peran operator sangat penting dalam penyemprotan untuk menghasilkan kristalisasi campuran $\mathrm{Pb}$ Sn dan dalam membersihkan penumpukan kristal pada bilah (barring).

\section{Referensi}

Arief, A. T. dan Gumilang, I. (2011) "Studi Analisis Penurunan Kadar Pb pada Crystallizer di Unit Metalurgi PT . Timah ( Persero ) Tbk Mentok Bangka Barat Provinsi Bangka Belitung,” in Seminar Nasional AVoER ke-3. Palembang: Universitas Sriwijaya, hal. 251-259.

Barata, D. (2006) Prosedur Operasi Standar Crystallizer. Koba.

Drini, B. (2006) Aluminium scrap refining with fractional layer crystallization. Kosovo: DCE - Drini Consulting \& Engineering. doi: 10.13140/RG.2.1.4527.8560.

Drini, B., Katgerman, L. dan Boom, R. (2005) "Metal refining with fractional crystallisation : Stateof-the-art and future prospects," Scandinavian Journal of Metallurgy, 34, hal. 1-10.

European Chemicals Agency (ECHA) (2020) Tin. 
Heyer, R. H. (1939) Engineering Physical Metallurgy. Massachusets: Plimpton Press.

Salim, Z. dan Munadi, E. (2016) Info Komoditi Timah. Jakarta Selatan: Badan Pengkajian dan Pengembangan Perdagangan. 